\title{
Autophagy Regulates the Stemness of Cervical Cancer Stem Cells [Retraction]
}

Yang Y, Yu L, Li J, et al. Autophagy regulates the stemness of cervical cancer stem cells. Biologics. 2017;11:71-79.

The Publisher, and Editor-in-Chief of Biologics: Target and Therapy wish to retract the published article.

Concerns were raised that this article contains instances of image manipulation, including images that appear to overlap with those published in the article: Fu R, Ding Y, Luo J, Yu L, Li CL, Li DS, Guo SW. TET1 exerts its tumour suppressor function by regulating autophagy in glioma cells. Biosci Rep. 2017;37(6): pii: BSR20160523. https:// doi.org/10.1042/BSR20160523

A summary of our concerns follows:

Figure 2, frame A (HBSS 8h-Adherent cells), rotated left $90^{\circ}$, appears to be an excerpt of Figure 2I (Wild) in Fu et al, 2017.

Figure 3, frames C (RAPA 12h) and E (HBSS 4h) appear to contain the same image with varied saturation.

Figure 3, these figures also appear identical to Figure 4B (wild type) in Fu et al, 2017.

Biologics: Targets and Therapy

\section{Publish your work in this journal}

Biologics: Targets and Therapy is an international, peer-reviewed journal focusing on the patho-physiological rationale for and clinical application of Biologic agents in the management of autoimmune diseases, cancers or other pathologies where a molecular target can be identified. This journal is indexed on PubMed Central, CAS, EMBase,
Figure 3, frame C (RAPA 0h), rotated right $180^{\circ}$, appears to be the same image as Figure 2, frame F (TET1) in Fu et al, 2017.

Figure 3, frame C (RAPA 24h), rotated $180^{\circ}$, appears to be the same image as Figure 4, frame B (Clone 1) in Fu et al, 2017.

Figure 3, frame E (HBSS $8 \mathrm{~h}$ ) appears to be the same images as Figure 2F (Wild) in (Fu et al, 2017).

Figure 5, frame B (3-MA) appears to overlap with Figure 4 (clone 2) in $\mathrm{Fu}$ et al, 2017, when Figure 4 is rotated left approximately $45^{\circ}$.

The editor determined the findings of the study were no longer valid and advised the article needed to be retracted. The authors have agreed with the decision to retract and wish to apologize for these errors.

Our decision-making was informed by our policy on publishing ethics and integrity and the COPE guidelines on retraction.

The retracted article will remain online to maintain the scholarly record, but it will be digitally watermarked on each page as "Retracted".
Scopus and the Elsevier Bibliographic databases. The manuscript management system is completely online and includes a very quick and fair peer-review system, which is all easy to use. Visit http://www.dovepress.com/testimonials.php to read real quotes from published authors. 